\title{
HISTORICAL SERIES OF PATIENTS WITH VISCERAL LEISHMANIASIS TREATED WITH MEGLUMINE ANTIMONIATE IN A HOSPITAL FOR TROPICAL DISEASES, MACEIÓ-AL, BRAZIL
}

Lindon Johoson Diniz SILVEIRA(1), Thiago José Matos ROCHA(2), Sandra Aparecida RIBEIRO(3) \& Célia Maria Silva PEDROSA(4)

\begin{abstract}
SUMMARY
Introduction: Visceral leishmaniasis is an endemic protozoan found in Brazil. It is characterized by fever, pallor, hepatosplenomegaly, lymphadenopathy, and progressive weakness in the patient. It may lead to death if untreated. The drug of choice for treatment is meglumine antimoniate (Glucantime ${ }^{\circledast}$ ). The aim of this study was to evaluate patients with visceral leishmaniasis according to criteria used for diagnosis, possible reactions to Glucantime ${ }^{\circledR}$ and blood pressure measured before and after treatment. Methods: 89 patients admitted to the Teaching Hospital Dr. Hélvio Auto (HEHA) in Maceió-AL, in the period from May 2006 to December 2009 were evaluated. Data were collected on age, sex, origin, method of diagnosis, adverse effects of drugs, duration of hospitalization, duration of treatment and dosage up to the onset of adverse effects. Results: There was a predominance of child male patients, aged between one and five years old, from the interior of the State of Alagoas. Parasitological diagnosis was made by bone marrow aspirate; three (3.37\%) patients died, $12(13.48 \%)$ had adverse reactions and treatment was changed to amphotericin B, and $74(83.14 \%)$ were cured. Changes that led to replacing Glucantime ${ }^{\circledR}$ were persistent fever, jaundice, rash, bleeding and cyanosis. Conclusion: During the study, 89 patients hospitalized for VL were analyzed: 74 were healed, 12 were replaced by amphotericin B treatment and three died. Most of them were under five years old, male and came from the interior. The dosage and duration of treatment with Glucantime ${ }^{\circledR}$ were consistent with that advocated by the Ministry of Health. Persistence of fever, jaundice, rash, cyanosis and bleeding were the reactions that led the physician to modify treatment. No change was observed in blood pressure before and after treatment. This study demonstrated the work of a hospital, a reference in the treatment of leishmaniasis, which has many patients demanding its services in this area. It demonstrates that this disease is still important today, and needs to be addressed properly to prevent injury and death due to the disease.
\end{abstract}

KEYWORDS: Glucantime; Visceral leishmaniasis; Hepatosplenomegaly.

\section{INTRODUCTION}

Visceral leishmaniasis (VL) is a major international public health problem, affecting approximately 65 countries with an estimated annual incidence of 500,000 new cases, 90\% of which occur in India, Nepal, Sudan, Bangladesh and Brazil. The fatalities are high, and an estimated 59,000 people die from the disease each year ${ }^{2}$. Currently, it is among the six endemic diseases prioritized in the world ${ }^{1}$.

The increased occurrence of Leishmania and HIV co-infection may be related in part to the geographical distribution of both pathologies ${ }^{3}$. In areas in which VL is endemic, people who are immunocompromised due to infection by HIV are more likely to develop clinical LV as compared to those without HIV co-infection. In fact, $L$. infantum co-infection is now the third most common infection in HIV-infected individuals in endemic areas of $\mathrm{VL}^{4}$. Rates of HIV infection are 5\% in Brazil, from $2-5 \%$ in India and vary between 25 and $40 \%$ in Ethiopia (WHO, 2010) ${ }^{28}$.
In Alagoas, 1076 cases of VL were reported in the last ten years (1999-2008), according to the Ministry of Health. The years with the highest number of cases were 1999 (171 cases), 2000 (285 cases) and 2001 (234 cases). The disease predominates in rural areas, affecting mainly children who live in these areas. Of the 102 municipalities in the State, VL has been reported in $89 \%$ of them. Over the past five years the municipalities that most reported cases were Arapiraca, Palmeira dos Índios, Traipú, Cacimbinhas, Igaci, Santana do Ipanema and São José da Tapera.

In Alagoas, the Teaching Hospital School Dr. Hélvio Auto (HEHA), maintained by the public service, is considered a reference by the National Health Service (NHS) for hospitalization of patients with infectious and parasitic diseases in the state of Alagoas.

In Brazil, pentavalent antimonials are the drug of choice for treatment of VL due to their proven therapeutic effectiveness ${ }^{6}$. Meglumine of

(1) Specialist in Health Sciences from the University of Health Sciences of Alagoas-UNCISAL. University Center Cesmac. E-mail: johoson@uol.com.br

(2) PhD in Therapeutic Innovation, Federal University of Pernambuco-UFPE. E-mail: thy_rocha@ hotmail.com

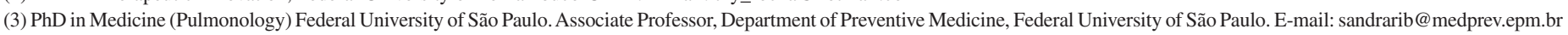

(4) PhD in Tropical Medicine from the Federal University of Pernambuco. III Associate Professor at the Federal University of Alagoas. E-mail: celpedrosa@ gmail.com

Correspondence to: Thiago J.M. Rocha, Universidade Federal de Pernambuco, Depto. Antibióticos, 50670-901 Recife, Pernambuco, Brasil. E-mail: thy_rocha@ hotmail.com 


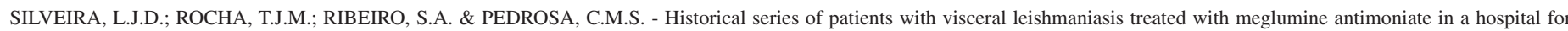
Tropical Diseases, Maceió-AL, Brazil. Rev. Inst. Med. Trop. Sao Paulo, 57(1): 33-8, 2015.

antimoniate (Glucantime ${ }^{\circledR}$ ) is especially effective in the treatment of cutaneous, mucocutaneous and visceral leishmaniasis. The drug causes rapid regression of clinical manifestations and hematological disease and causes sterilization of the parasite ${ }^{7}$. However, recent research has shown an increase in the number of reports of adverse reactions to Glucantime ${ }^{\circledR}$.

Knowing that VL is a frequent cause of hospitalization in HEHA and that most patients are treated with Glucantime ${ }^{\circledR}$, the authors developed an interest in seeing how these patients would present, taking into account the general characteristics, the criteria used for the diagnosis, possible effects of the Glucantime ${ }^{\circledR}$ and blood pressure measured before and after treatment. The research aimed to study the cases of VL admitted to the HEHA from 2006 to 2009 in Maceió-AL.

\section{MATERIALS AND METHODS}

Study area: The State of Alagoas is located in Northeastern Brazil, and consists of 102 municipalities having an area of $27,767 \mathrm{~km}^{2}$ and a population of 3,156,108 inhabitants. Alagoas is the most populous state in the Northeast of Brazil with a population density of 101.3 inhabitants per $\mathrm{km}^{2}$. The urban population accounts for $68.01 \%$ of the total group of children and adolescents and accounts for $28.26 \%$ of the population with 797,931 inhabitants.

Study type: Observational, cross-sectional and descriptive.

Study site: The site where the research was conducted HEHA, belonging to the State University of Health Sciences of Alagoas (UNCISAL), located in the city from Maceió, AL.

Data collection: Data collection began in May 2006 and ended in December 2009. All patients admitted to HEHA diagnosed with VL were selected, and they were treated with Glucantime ${ }^{\circledast}$. During this period, 89 patients were included. All patients, after being diagnosed with VL, were invited to sign a consent form (ICF).

Research subjects: In the period from May 2006 to December 2009 patients admitted with a diagnosis of VL were invited to participate in the study and were prescribed treatment with Glucantime ${ }^{\circledR}$. For children, an authorized guardian permitted their participation in the research.

Inclusion criteria: The study included all clinical-epidemiological, serological or parasitological patients confirmed to have VL, who were admitted and prescribed treatment with Glucantime ${ }^{\circledR}$. Clinical and epidemiological diagnosis was considered for patients who had fever and Hepatosplenomegaly and were native to areas considered endemic areas.

Exclusion criteria: The study excluded patients who were prescribed treatment with other medicines than Glucantime ${ }^{\circledR}$. There were no refusals.

Patient sex: Gender was raised in the study with the proposition to investigate the distribution of VL cases according to the respective groups: male and female.

Age of the patient: In the study, patients were divided into groups as follows: patients $<1$ year, patients one to five years, patients six to 10 years, patients 11 to 20 years, patients 21 to 30 years, patients 31-40 years, patients 41-50 years, 51-60 years, 61-70 years and 71-80 years.
Weight: The study used a variable weight, whereby the daily dose of Glucantime ${ }^{\circledR}$ is calculated according to the weight of the patient.

Patient's origin: As HEHA caters to all patients referred with suspected VL, in another 44 municipalities in Alagoas beyond the capital, the record of this variable will allow a better characterization of the study population as there are endemic municipalities. The data were computed with the name of the municipality and then were cataloged in the physiographic regions of the State (Coastal, Zona da Mata, Wasteland and Hinterland).

Type diagnosis: Patients with VL can be diagnosed using two criteria: clinical criteria and laboratory clinical epidemiological criteria. Therefore this variable was recorded so that they could relate them to other variables.

Period of stay: Treatment for VL using Glucantime ${ }^{\circledR}$ as a first-choice drug can last 30 days on average and depending on the patient's condition, they may be hospitalized during this period. The date of admission and date of discharge was noted.

Treatment period: Knowing that the drug research topic is Glucantime $^{\circledR}$ and the duration of the treatment is the same, on average 30 days, the date of initiation of treatment and end date of the treatment was computed. The annotation of this variable was important for the Glucantime ${ }^{\circledR}$ treatment because various adverse reactions may lead to treatment discontinuation.

Dosage: The recommended dose in the study and used for the treatment of visceral leishmaniasis with Glucantime ${ }^{\circledR}$ was $20 \mathrm{mg} \mathrm{Sb}+5$ $\mathrm{kg}$ /day with intravenous application (IA) or intramuscular (IM) for at least 20 and up to 40 days, using the maximum two to three vials/day. The Glucantime ${ }^{\circledR}$ ampoules had $5 \mathrm{~mL}$ containing up to $1500 \mathrm{mg}$ (300 $\mathrm{mg} / \mathrm{mL})$ equivalent to $405 \mathrm{mg}(81 \mathrm{mg} / \mathrm{mL})$ pentavalent antimony ( $\mathrm{Sb}$ ${ }^{+5}$ ). In adult patients, Amphotericin B was used at a dose of $1 \mathrm{mg} / \mathrm{kg}$ on alternate days (maximum total dose of $3 \mathrm{~g}$ ). In children, it was used at a dose of 15 to $25 \mathrm{mg} / \mathrm{kg}$, also administered on alternate days.

Amendment(s) that motivated (plow) treatment interruption: All clinical and adverse reactions that led the doctor to replace treatment with Glucantime ${ }^{\circledR}$ with another drug were noted.

Cure criteria: The cases were followed up to six months after treatment completion and the cure criteria used was a good clinical response to treatment with disappearance of fever and reduction of hepatosplenomegaly.

Data analysis: After collection, the data were stored in a spreadsheet (Microsoft Excel $2003^{\circledR}$. Redmond, WA, USA) as the database. The results were tabulated and frequencies of the variables in each group were calculated and arranged in tabular and graphic formats. The tabulated data were processed by the application Microcomputer Statistical Package for Social Sciences (SPSS ${ }^{\odot}$ ) (version 15.0 for Windows, SPSS Inc). The descriptive statistics for numeric variables included calculations of the mean and standard deviation (SD).

Ethical considerations: This research project was developed according to the international guidelines that deal with human research, 


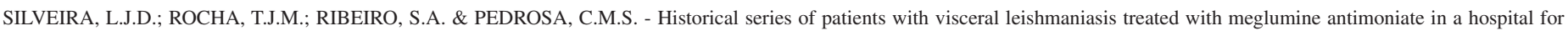
Tropical Diseases, Maceió-AL, Brazil. Rev. Inst. Med. Trop. Sao Paulo, 57(1): 33-8, 2015.

notably resolution 196/96 of the National Health Council (CNS).

\section{RESULTS}

During the research following a specified protocol, patients admitted to the HEHA in Maceió-AL, in VL diagnosis were treated with the drug Glucantime ${ }^{\circledR}$ from May 2006 to December 2009.

After confirmation of the diagnosis of VL, 89 patients were included who started treatment with Glucantime ${ }^{\circledR}$. Three patients $(3.37 \%)$ died, 12 patients $(13.48 \%)$ had adverse reactions and treatment was changed to amphotericin B, 74 patients $(83.14 \%)$ who continued to be treated with Glucantime ${ }^{\circledR}$ were cured of the disease.

The duration of treatment for all 89 patients ranged from one to 40 days with a mean of $24.42(\mathrm{SD}= \pm 10.04)$ and the cumulative dose in $\mathrm{mg}$ ranged from $340 \mathrm{mg}$ to $44640 \mathrm{mg}$ with an average of $13808(\mathrm{SD}= \pm 11950)$.

Of the total 89 patients studied, $52(58.4 \%)$ were male and 37 $(41.5 \%)$ female. During the observation period the patients were from 33 municipalities in Alagoas. The municipality with the highest number of cases was São José da Tapera with 12 (13.48\%), followed by Girau Ponciano with seven (7.87\%), Palmeira dos Índios and Traipú with six $(6.74 \%)$ and other municipalities between five and one patients. The highest incidence was found in the municipalities of the state.

The patients' ages ranged from nine months to 73 years, with a mean of $13.58(\mathrm{SD}= \pm 17.22)$ and a median of five. In this research the most affected age group was that of patients 1-5 years and decreased with increasing age: $<1$ year (1), 1-5 years (45), 10-20 years (12), 20-30 $(-10), 30-40$ years $(7), 40-50$ years $(6), 50-60$ years $(1), 60-70(4), 70-80$ years $(2),>80(1)$.

During the research period there were three deaths $(3.37 \%)$ in those patients who used Glucantime ${ }^{\circledR}$, only one was aged under five years and the other two over 60 years.

Of the patients who died (three from 89), all with positive parasitological tests, two patients had treatment duration for a period shorter than 10 days and the third had 25 days of treatment. The cumulative dose of Glucantime ${ }^{\circledR}$ administered in $\mathrm{mg} / \mathrm{kg}$ until death in the first patient was $400 \mathrm{mg}$, in the second patient $8544 \mathrm{mg}$, and the third $28555 \mathrm{mg}$.

Patients who were admitted to the HEHA, from May 2006 to December 2009 with VL showed the following distribution according to age and sex (Table 1).

For the diagnosis of VL all patients underwent bone marrow aspiration which identified 68 patients $(76.40 \%)$ as positive, $18(20.20 \%)$ were considered positive by clinical epidemiological criteria and only three $(3.40 \%)$ were positive by serological method (IIF) (Table 2).

Of the total 89 patients, $12(13.48 \%)$ had clinical changes that led to replacement of Glucantime ${ }^{\circledR}$. The main changes were persistent fever in five patients $(41.68 \%)$, jaundice in three patients $(25 \%)$, rash in two patients $(16.66 \%)$, bleeding in one patient $(8.33 \%)$ and also cyanosis in one patient $(8.33 \%)$.
Table 1

Distribution of VL patients by sex and age in HEHA, Maceió, 2006-2009

\begin{tabular}{lcccc}
\hline Age (years) & Male & Female & Total & $\%$ \\
\hline$<1$ & 1 & 0 & 1 & 1.12 \\
$1-5$ & 21 & 24 & 45 & 50.56 \\
$6-10$ & 6 & 6 & 12 & 13.48 \\
$11-20$ & 8 & 2 & 10 & 11.23 \\
$21-30$ & 5 & 2 & 7 & 7.86 \\
$31-40$ & 5 & 1 & 6 & 6.74 \\
$41-50$ & 0 & 1 & 1 & 1.12 \\
$51-60$ & 4 & 0 & 4 & 4.49 \\
$61-70$ & 1 & 1 & 2 & 2.24 \\
$71-80$ & 1 & 0 & 1 & 1.12 \\
\hline Total & $\mathbf{5 2}$ & $\mathbf{3 7}$ & $\mathbf{8 9}$ & $\mathbf{1 0 0}$ \\
\hline
\end{tabular}

Table 2

Method for VL diagnosis by age, HEHA, Maceió, 2006-2009

\begin{tabular}{lcccc}
\hline \multirow{2}{*}{ Age group } & \multicolumn{4}{c}{ DIAGNOSIS } \\
\cline { 2 - 5 } & Parasitological & $\begin{array}{c}\text { Clinical- } \\
\text { epidemiological }\end{array}$ & I.F.I & TOTAL \\
\hline$<$ 1 year & 0 & 0 & 1 & 1 \\
1 - 5 years & 38 & 6 & 1 & 45 \\
6 - 10 years & 7 & 5 & 0 & 12 \\
11 - 20 years & 6 & 3 & 1 & 10 \\
21 - 30 years & 6 & 1 & 0 & 7 \\
31 - 40 years & 4 & 2 & 0 & 6 \\
41 - 50 years & 0 & 1 & 0 & 1 \\
51 - 60 years & 4 & 0 & 0 & 4 \\
61 - 70 years & 2 & 0 & 0 & 2 \\
71 - 80 years & 1 & 0 & 0 & 1 \\
\hline TOTAL & $\mathbf{6 8}$ & $\mathbf{1 8}$ & $\mathbf{3}$ & $\mathbf{8 9}$ \\
\hline
\end{tabular}

It can be seen that 11 patients with clinical abnormalities were aged below five years and only one above 70 . The length of treatment before the onset of the reactions ranged from one to 11 days with a mean of $5.08(\mathrm{SD}= \pm 2.84)$ and the cumulative dose in $\mathrm{mg} / \mathrm{kg}$ of Glucantime ${ }^{\circledR}$ ranged from 340 to $7644 \mathrm{mg}$ with a mean of 1775 .

Of the 12 patients who had some type of clinical change after they received Glucantime ${ }^{\circledR}, 11(91.66 \%)$ of them reacted up to 10 days of hospitalization and only one $(8.34 \%)$ showed a reaction between the tenth and twentieth day of treatment. Patients who were cured of the disease ( 74 from 89) during the search using treatment as Glucantime ${ }^{\circledR}$ had a mean hospital stay of 19.6 days ( $\mathrm{SD}= \pm 11.4$ ), the duration of treatment ranged from 21 to 40 days with an average of 29.18 days. When correlated with the time of admission, age was a negative correlation between length of stay and age (Fig. 1).

The measurement of blood pressure before treatment occurred shortly after the diagnosis of VL and verification after treatment, which occurred on average 30 days after starting treatment with the drug Glucantime ${ }^{\circledR}$. All patients were normotensive and did not show any significant change in 


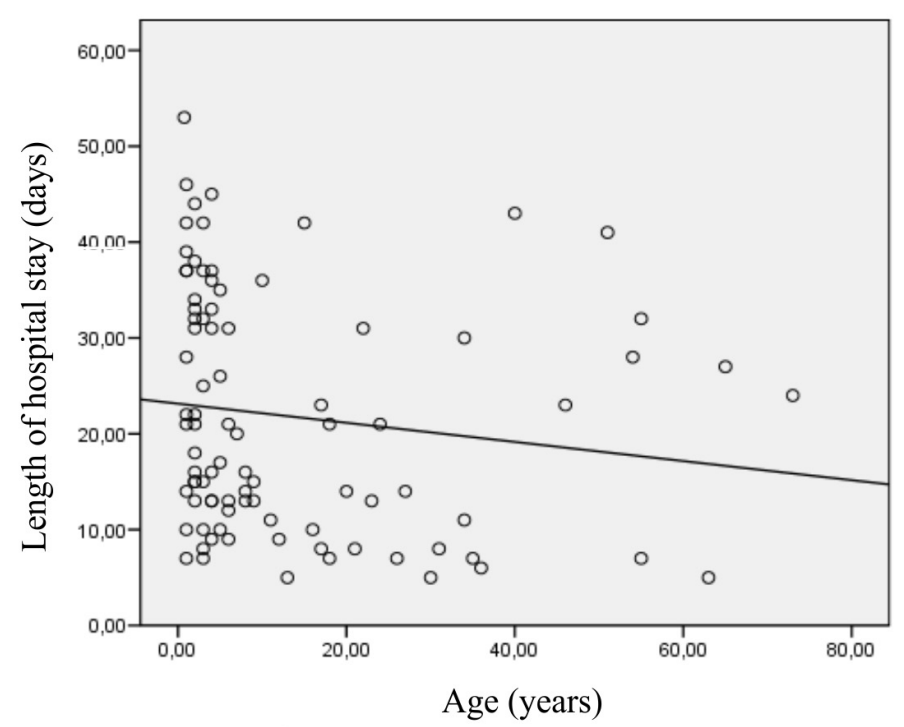

$r=-0,327$

$\mathbf{p}=\mathbf{0 , 0 0 2}$

Fig. 1 - Correlation length of stay with the age of patients hospitalized for LV, HEHA, Maceio, 2006-2009.

systolic values and diastolic BP. No patient was taking antihypertensive drugs.

\section{DISCUSSION}

From May 2006 to December 2009 a total of 130 patients with a diagnosis of VL in the HEHA were seen and treated, and $89(68.5 \%)$ were prescribed treatment with the drug of choice Glucantime ${ }^{\circledR} .41$ patients were treated with amphotericin $\mathrm{B}$, which is the drug of second choice for treatment of VL; this occurred because some patients presented contraindications and other unsatisfactory responses to Glucantime ${ }^{\circledR}$. This substitution occurred mostly because the patients had a liver problem and/or renal impairment.

The ages of the 89 patients in this study ranged from nine months to 73 years with a mean of 13.58 and a median of five. In a similar study of 114 patients in New Delhi, India, ages ranged from six months to 68 years and the average was 31 years $^{13}$.

In research conducted on the expansion of VL in the state of Mato Grosso-BR, between January 1998 and December 2005, predominance was found in males $(58 \%)$ and in ages $0-9$ years $(51.5 \%)^{15}$. The same happened with the present study, verifying the predominance of males at $58.42 \%$ and of age with $0-9$ years at $65.16 \%$. Even in developed countries like France the prevalence of cases occur in children under five years of age $(77 \%)^{12}$.

As HEHA, where the research was conducted, is a referral hospital for the entire state of Alagoas for VL treatment, 33 patients were studied from $(32.35 \%)$ municipalities in Alagoas for a total of 102 . The municipality of Alagoas had a higher incidence of cases with 12 (13.48\%); São José da Tapera was located in the hinterland of the state. This may be justified since São José da Tapera has one of the lowest Human Development Indices (HDI) in the state at 0.588 , and may also be due to a lack of sanitation and the custom of the inhabitants of rural communities to raise domestic $\operatorname{dog} s^{6}$.

Most patients in this study were from the state (81.8\%). A similar percentage $(77.0 \%)$ was also found in another study of children under 15 years old coming from Alagoas, where they studied clinical and epidemiological aspects of these children ${ }^{20}$. A survey in the state of Pernambuco found that $82.5 \%$ of patients' origins were concentrated within the state and $14.8 \%$ from the metropolitan region of Recife ${ }^{21}$.

In Tunisia, a study researching VL cases between 1996 and 2006 found that $65.3 \%$ lived in rural areas ${ }^{4}$. Although there is a work related urbanization $\mathrm{VL}^{17}$, one must realize that it is still a disease coming from inside. It is worth noting that there are factors associated with this internalization that make for a breeding reservoir for the disease: dogs, a lack of sanitation, and the low education and precarious socioeconomic conditions of the affected population that causes ignorance about the form of transmission ${ }^{16}$.

All 89 patients were submitted to parasitological diagnosis by bone marrow puncture. Of this total $68(76.40 \%)$ were positive and 21 (23.60\%) negative. Among those who were negative in the bone marrow puncture, three were confirmed by immunological method IFIs and the others were treated based on clinical epidemiological criteria. A study in Madrid, Spain, confirms this finding, predominantly diagnosed by bone marrow aspirate with $77 \%$ of patients in research. Based on these findings the diagnosis of VL by finding the parasite in bone marrow aspirate remains the diagnostic test performed in the area ${ }^{26}$.

The diagnosis made by the finding of developmental forms of Leishmania in bone marrow smears is a quick and easy one, while the IFI technique, despite the presence of some false-negatives, emerged as the most specific ${ }^{27}$.

Some studies confirmed the efficacy of treatment with Glucantime ${ }^{\circledR}$, although there is still little known about its mechanism of action ${ }^{3}$.

During the last two decades, the emergence of resistance to pentavalent antimonials had a huge impact on the epidemiology of leishmaniasis ${ }^{10}$. Authors consider pentavalent antimony safe for the treatment of leishmaniasis, although the reports of adverse effects are increasing ${ }^{24}$. Adverse effects such as elevated serum liver and pancreas enzymes were found in a study comparing patients who used Glucantime ${ }^{\circledR}$ with patients who received pentamidine ${ }^{25}$. They are described in further research as electrocardiographic changes, myalgia, headache, rash, nephritis, gastrointestinal and respiratory disorders ${ }^{7,14,22}$.

The cardiotoxicity associated with high doses and duration of treatment, is the most serious side effect with the use of Glucantime ${ }^{\circledR 23}$. Other authors also suggest that it is necessary to evaluate electrocardiographic tests during treatment with pentavalent antimonials regardless of the presence of factors that increase the risk of cardiac disease ${ }^{24}$.

During the study 89 patients were evaluated using the drug Glucantime $^{\circledR}$ for treatment of VL. Treatment was interrupted in 12 $(13.48 \%)$ patients because of clinical alterations that compromised the 


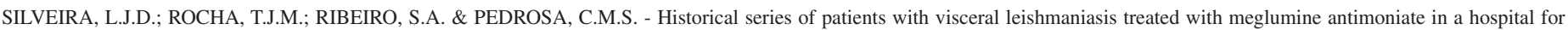
Tropical Diseases, Maceió-AL, Brazil. Rev. Inst. Med. Trop. Sao Paulo, 57(1): 33-8, 2015.

continuity of treatment with Glucantime ${ }^{\circledR}$. In a study with 55 patients, seven $(12.72 \%)$ of these patients had poor response to antimony, characterized by continuing of signs and symptoms and/or worsening of the clinical picture ${ }^{18}$.

Of the 12 patients who had clinical changes with the use of Glucantime $^{\circledR}$, two $(16.66 \%)$ had a rash; the same occurred in Research Study 18 in which one patient out of 11 was found with the same reaction and in Study 3, 21 subjects presented with a $\operatorname{rash}^{19}$. Failure of treatment with Glucantime ${ }^{\circledR}$ was also found in another study, involving $16(10.1 \%)$ of 158 patients in a retrospective analysis in the Protozoology Unit of the Istituto Superiore di Sanità (Italian National Institute of Health) ${ }^{8}$.

The other reactions that led to treatment failure were persistent fever, jaundice, cyanosis and bleeding. The reactions presented occurred in the vast majority, 11 of 12 patients during the first 10 days of treatment and the age group affected by these reactions was $0-5$ years, with five patients less than one year, six patients in the range one - five years and only one patient over 70 years old. As a result of these reactions, treatment was replaced by amphotericin $\mathrm{B}$, the second drug of choice for treatment of VL recommended by the Ministry of Health.

Among the 89 patients, 74 (83.14\%) were treated with Glucantime ${ }^{\circledast}$ for the period and dose according to Ministry of Health and were considered cured according to clinical and laboratory criteria. Clinical criteria were: disappearance of fever and reduction of hepatosplenomegaly. At the end of treatment the spleen usually decreased by $40 \%$ or more compared to baseline. With respect to laboratory criteria the improvement of hematological parameters (hemoglobin, leukocytes and platelets) and a return to normal reference values of liver enzymes (AST and ALT) were taken into account. Patient follow-up was done at 3, 6 and 12 months after treatment and if, at the last evaluation he remained stable, the patient was considered cured.

During the treatment, three $(3.37 \%)$ patients died. Of the three patients that died after the use of Glucantime ${ }^{\circledR}$, two of these occurred within ten days after the start of treatment. These deaths were not attributed to medication because these two patients were one and 63 years old, respectively, and upon showing clinical signs were admitted to the hospital; drug administration occurred only at two and seven days, respectively. The third death occurred in a patient 65 years old who had a stroke (cerebrovascular accident) during hospitalization and died after 25 days of treatment with Glucantime $^{\circledR}$. It can be observed that the deaths are not related to dosage.

A similar finding was observed in a study in Pernambuco, which recorded 44 deaths, in which the average hospital stay was 10 days $(\mathrm{SD}= \pm 9)$, and the main immediate causes of death were associated infections, bleeding and liver failure ${ }^{21}$. In the account given by other authors, a 45-year old patient was treated with Glucantime ${ }^{\circledR}$ for 30 days, and death did not occur until ten days after the end of this thirty day treatment and the cause of death was considered sudden death ${ }^{18}$.

In a retrospective analysis of four confirmed cases of VL who were admitted to the Hospital Municipal de Santo André, it was seen that two patients died in the first week of treatment, indicating that these deaths were caused by the phenomenon of hypersensitivity or more likely the development of septicemia in patients already immunocompromised ${ }^{5}$. In another study, one hypertensive and diabetic patient who was 58 years old, treated with Glucantime ${ }^{\circledR}$ died on day 18 of treatment from coronary artery disease, likely acute ${ }^{9}$.

When the blood pressure was observed before and after treatment during research it was seen that there was no significant increase or decrease in normotensive remaining and no patient had hypertension prior to the start of the treatment, nor was there any use of antihypertensive drugs. It had already been observed in another study that while nine of 23 patients studied had hypertension, patients were mostly adults and the sample was small, while in the present study the sample was bigger and patients were mostly younger than 10 years old ${ }^{11}$.

Given the prevalence of cases of VL in Alagoas it should guide the medical profession operating there to the appreciation of the signs and symptoms of the disease so that specific therapy can begin as soon as possible, thereby avoiding a worsening of the patient's prognosis. Early treatment reduces the risk of death, especially in children, and increases the cure rate.

The reporting of adverse reactions must be continuous and efficient and well publicized so that everyone can know all those cases that are not reported in the current literature. The city of São José da Tapera, inside Alagoas, should plan reduction targets of cases of VL since both this study and in others in this municipality, Alagoas remains among those with a higher incidence of new cases.

\section{CONCLUSIONS}

During the research, 89 patients with visceral leishmaniasis were included in the study, treated with Glucantime ${ }^{\circledR}$, and 74 patients were considered cured, 12 had reactions that led to the replacement of Glucantime $^{\circledast}$ with amphotericin B for treatment, and three died. The mean hospital stay was 22 days. Among the patients studied most were less than five years of age, male, and from the interior of the state. The dose of Glucantime ${ }^{\circledR}$ and the period of treatment during the study were consistent with the recommendations of the Ministry of Health. The reactions that led the doctor to replace treatment by amphotericin B were: persistent fever, jaundice, rash, cyanosis and bleeding. All patients were normotensive and there was no change in blood pressure before and after treatment with Glucantime ${ }^{\circledR}$.

\section{CONFLICT OF INTEREST}

The authors declare that there is no conflict of interest.

\section{RESUMO}

\section{Série histórica dos pacientes com leishmaniose visceral tratados com antimoniato de meglumina em hospital de Doenças Tropicais, Maceió-AL, Brasil}

A Leishmaniose visceral é doença infecciosa causada por protozoários das espécies chagasi e donovani sendo transmitida pela picada de insetos fêmea dos gêneros Lutzomyia e Phlebotomos. Constitui doença febril, determinando amplo aspecto de manifestações clínicas e prognóstico variável, que pode levar à morte se não for tratada. É doença endêmica encontrada no Brasil e nos últimos anos verificou-se intenso processo de urbanização da endemia e aumento da letalidade por leishmaniose 
SILVEIRA, L.J.D.; ROCHA, T.J.M.; RIBEIRO, S.A. \& PEDROSA, C.M.S. - Historical series of patients with visceral leishmaniasis treated with meglumine antimoniate in a hospital for Tropical Diseases, Maceió-AL, Brazil. Rev. Inst. Med. Trop. Sao Paulo, 57(1): 33-8, 2015.

visceral. O estudo teve como objetivo avaliar pacientes com leishmaniose visceral de acordo com os critérios utilizados para o diagnóstico, possíveis reações ao Glucantime® e pressão arterial, medidos antes e após o tratamento. Métodos: Foram avaliados 89 pacientes internados no Hospital Universitário Dr. Hélvio Auto (HEHA), em Maceió-AL, no período de maio de 2006 a dezembro de 2009. Foram coletados dados sobre idade, sexo, origem, método de diagnóstico, efeitos adversos da droga, duração da hospitalização, duração do tratamento e dose até o aparecimento de efeitos adversos. Resultados: Houve predomínio de crianças do sexo masculino, com idade entre um e cinco anos, a partir do interior do Estado de Alagoas. O diagnóstico parasitológico foi feito pelo aspirado de medula óssea, três $(3,37 \%)$ pacientes morreram, $12(13,48 \%)$ apresentaram reações adversas e o tratamento foi alterado para anfotericina B, e $74(83,14 \%)$ foram curados. As alterações que levaram à substituição de Glucantime® foi febre persistente. A dosagem e duração do tratamento com Glucantime ${ }^{\circledR}$ foi seguido como preconizado pelo Ministério da Saúde. A persistência de febre, icterícia, prurido, cianose e sangramento foram as reações que levaram o médico a modificar o tratamento. Nenhuma mudança foi observada na pressão arterial antes e após o tratamento. O estudo realizado demonstrou o perfil de um Hospital, que recebe grande demanda de casos de leishmaniose visceral. Isso demonstra que essa doença continua sendo importante na atualidade, precisando ser abordada de maneira adequada, evitando assim agravos e mortes pela doença.

\section{REFERENCES}

1. Altman DG. Practical statistics for medical research. London: Chapman \& Hall/CRC; 1991.

2. Alvarenga DG, Escalda PMF, Costa ASV, Monreal MTFD. Leishmaniose visceral: estudo retrospectivo de fatores associados à letalidade. Rev Soc Bras Med Trop. 2010;43:194-7

3. Andersen EM, Cruz-Saldarriaga M, Llanos-Cuentas A, Luz-Cjuno M, Echevarria J, Miranda-Verastegui $\mathrm{C}$, et al. Comparison of meglumine antimoniate and pentamidine for Peruvian cutaneous leishmaniasis. Am J Trop Med Hyg. 2005;72:133-7.

4. Aoun K, Jeddi F, Amri F, Ghrab J, Bouratbine A. Actualités épidémiologiques de la leishmaniose viscérale en Tunisie. Med Mal Infect. 2009;39:775-9.

5. Ayub MA, Moretti AE, Mozetic V, Koiffman E, Silveira KF, Martins MSV. Agravamento da leucopenia e morte súbita durante o tratamento de Calazar. Arq Med ABC. 1992;15(2):19-21.

6. Cerbino Neto J, Werneck GL, Costa CHN. Factors associated with the incidence of urban visceral leishmaniasis: an ecological study in Teresina, Piauí State, Brasil. Cad Saude Publica. 2009;25:1543-51.

7. Cucé LC, Júnior WB, Dias MC. Alterações renais por hipersensibilidade ao uso de antimonial pentavalente (Glucantime ${ }^{\circledR}$ ) na leishmaniose tegumentar americana: relato de caso. Rev Inst Med Trop Sao Paulo. 1990;32:249-51.

8. Gradoni L, Gramiccia M, Scalone A. Visceral leishmaniasis treatment, Italy. Emerg Infect Dis. 2003;9:1617-20

9. Lima MVN, Oliveira RZ, Lima AP, Cerino DA, Silveira TGV. Leishmaniose cutânea com desfecho fatal durante o tratamento com antimonial pentavalente. An Bras Dermatol. 2007;82:269-71.

10. Maltezou HC. Visceral leishmaniasis: advances in treatment. Recent Pat Antiinfect Drug Discov. 2008;3:192-8

11. Marzochi MCA, Sabroza PC, Toledo LM, Marzochi KBF, Tramontano NC, Rangel Filho FB. Leishmaniose visceral na cidade do Rio de Janeiro-Brasil. Cad Saude Publica. 1985;1:5-17.
12. Marty P, Pomares-Estran C, Hasseine L, Delaunay P, Haas H, Rosenthal E. Actualités sur les leishmanioses en France. Arch Pédiatr. 2009;16(Suppl 2):S96-100.

13. Mathur P, Samantaray JC, Samanta P. High prevalence of functional liver derangement in visceral leishmaniasis at an Indian tertiary care center. Clinic Gastroenterol Hepatol. 2008:6:1170-2.

14. Medeiros FS, Tavares-Neto J, D’Oliveira A Jr, Paraná R. Alteraciones hepáticas en la leishmaniasis visceral (Kalazar) en niños: revisión sistemática de la literatura. Acta Gastroenterol Latinoam. 2007;37:150-7.

15. Mestre GLC, Fontes CJF. A expansão da epidemia da leishmaniose visceral no Estado de Mato Grosso, 1998-2005. Rev Soc Bras Med Trop. 2007;40:42-8.

16. Nascimento ELT, Martins DR, Monteiro GR, Barbosa JD, Ximenes MFFM, Maciel BL, et al. Forum: geographic spread and urbanization of visceral leishmaniasis in Brazil. Postscript: new challenges in the epidemiology of Leishmania chagasi infection. Cad Saude Publica. 2008;24:2964-7.

17. Oliveira CDL, Morais MHF, Machado-Coelho GLL. Visceral leishmaniasis in large Brazilian cities: challenges for control. Cad Saude Publica. 2008;24:2953-8.

18. Oliveira JM, Fernandes AC, Dorval MEC, Alves TP, Fernandes TD, Oshiro ET, et al. Mortalidade por leishmaniose visceral: aspectos clínicos e laboratoriais. Rev Soc Bras Med Trop. 2010;43:188-93.

19. Oliveira MC, Amorim RFB, Freitas RA, Costa ALL. Óbito em caso de leishmaniose cutâneomucosa após o uso de antimonial pentavalente. Rev Soc Bras Med Trop. 2005;38:258-60.

20. Pedrosa CMS, Rocha EMM. Aspectos clínicos e epidemiológicos da leishmaniose viscera em menores de 15 anos procedentes de Alagoas, Brasil. Rev Soc Bras Med Trop. 2004;37:300-4.

21. Queiroz MJA, Alves JGB, Correia JB. Leishmaniose visceral: características clínicoepidemiológicas em crianças de área endêmica. J Pediatr (Rio J). 2004;80:141-6.

22. Rath S, Trivelin LA, Imbrunito TR, Tomazela DM, Jesús MN, Marzal PC, et al Antimoniais empregados no tratamento da leishmaniose: estado da arte. Quim Nova. $2003 ; 26: 550-5$.

23. Ribeiro ALP, Drummond JB, Volpini AC, Andrade AC, Passos VMA. Electrocardiographic changes during low-dose, short-term therapy of cutaneous leishmaniasis with the pentavalent antimonial meglumine. Braz J Med Biol Res. 1999;32:297-301.

24. Saldanha ACR, Romero GAS, Guerra C, Merchan-Hamann E, Macedo VO. Estudo comparativo entre estibogluconato de sódio BP $88 \AA$ e antimoniato de meglumina no tratamento da leishmaniose cutânea. II. Toxicidade bioquímica e cardíaca. Rev Soc Bras Med Trop. 2000;33:383-8.

25. Shahian M, Alborzi A. Effect of meglumine antimoniate on the pancreas during treatment of visceral leishmaniasis in children. Med Sci Monit. 2009;15:290-3.

26. Tato LMP, Izquierdo ELO, Martín SG, Lobato ES, Esteban CG, García-Bermejo I, Amador JTR. Diagnóstico y tratamiento de la leishmaniasis visceral infantil. An Pediatr (Barc). 2010;72:347-51

27. Zougaghi L, Moutaj R, Chabaa L, Agoumi A. Leishmaniose viscérale infantile: profil épidémiologique, clinique et biologique. À propos de 93 cas. Arch Pediatr. 2009;16:1513-8

28. World Health Organization. Control of the leishmaniasis: report of a meeting of the WHO Expert Committee on the Control of Leishmaniasis. World Health Organ Tech Rep Ser. 2010;949:1-186.

Received: 19 July 2013

Accepted: 27 May 2014 